\title{
Augmented Deneme Desenine Dayalı Ekmeklik Buğday Genotiplerinin (Triticum aestivum L.) Diyarbakır Yağışa Dayalı Şartlarında Bazı Tarımsal Özellikler Yönünden Değerlendirilmesi
}

\author{
Mehmet KARAMAN ${ }^{1} \mathscr{\&}$, Mahir BAŞARAN ${ }^{2}$, İfan ERDEMCí ${ }^{3}$, Mustafa OKAN $^{4}$ \\ ${ }^{1}$ Bitkisel Üretim ve Teknolojileri Bölümü, Uygulamalı Bilimler Fakültesi, Muş Alparslan Üniversitesi, Muş, \\ Türkiye \\ ${ }^{2,3,4}$ GAP Uluslararası Tarımsal Araştırma ve Eğitim Merkezi Müdürlüğü, Diyarbakır, Türkiye \\ 凶: m.karaman@alparslan.edu.tr (iD)10000-0002-6176-9580, (iD)20000-0002-9655-0992, \\ 0000-0003-3066-410X, (iD 4 40000-0001-7642-3849
}

Geliş (Received): 05.03.2021Ｄüzeltme (Revision): 17.05.2021～Kabul (Accepted): 30.05.2021

\begin{abstract}
$\ddot{O Z Z}$
Çalışma, Diyarbakır merkez lokasyonunda 2018-2019 üretim sezonunun yağışa dayalı koşullarında yürütülmüştür. Araştırma materyalini farklı tabiatlı ekmeklik buğday genotipleri oluşturmuştur. Çalışma, Augmented Deneme Deseninde 6 blokta yürütülmüş olup, araştırma konusu 120 hat, 5 kontrol çeşit ile kıyaslanmıştır. Araştırma sonuçlarına göre; incelenen tüm özellikler yönünden genotipler arasında $\mathrm{p} \leq 0.01 \mathrm{ve}$ $\mathrm{p} \leq 0.05$ düzeyinde önemli farkl1lıklar olduğu belirlenmiştir. Araştırmada, tane verimi; $186.3-813.0 \mathrm{~kg} \mathrm{da}^{-1}$, hektolitre ağırlığı; 76.01-84.91 kg hl${ }^{-1}$, bin tane ağırlığı; 23.51-46.71 g ve protein oranı; \%8.67-12.61 arasında değişmiştir. Genotiplere ait veriler kullanılarak yapılan biplot analizine göre hektolitre ağırlığı ile bin tane ağırlı̆̆ 1 arasında pozitif korelasyon olduğu belirlenirken, protein oranı ile tane verimi arasında negatif korelasyon olduğu görülmüştür. Üstün hatlar genetik tabanı zenginleştirmek için işaretlenerek genitör olarak gen havuzuna alınmıştır. Ayrıca, aynı hatlar ileri kademe verim denemelerine aktarılarak farklı çevrelerde en az 3 yıl denenmek suretiyle ıslah süreçlerinin devam ettirilmesi gerektiği sonucuna varılmıştır.
\end{abstract}

Anahtar Kelimeler: Seleksiyon, kalite, buğday, genotip

\section{Evaluation of Some Agricultural Characteristics of Bread Wheat (Triticum aestivum L.) Genotypes Based on Augmented Experimental Design in Diyarbakır Rainfall Conditions}

\begin{abstract}
The study was carried out based on rainfall conditions in the 2018-2019 growing season in center of Diyarbakir location. The research material consisted of different natured bread wheat genotypes. This study was designed as Augmented Experimental Design with 6 blocks, and 120 lines, being the subject of this study, was compared with 5 control variety. According to results; It was determined that there were significant differences between the genotypes in the $\mathrm{p} \leq 0.01$ and $\mathrm{p} \leq 0.05$ level in terms of all the examined features. It was determined that grain yield; $186.3-813.0 \mathrm{~kg} \mathrm{da}^{-1}$, test weight; $76.01-84.91 \mathrm{~kg} \mathrm{~h}^{-1}$, thousand grain weight; $23.51-46.71 \mathrm{~g}$ and protein ratio; \%8.67-12.61 ranged. According to the biplot analysis using genotypes data, it was determined that there was a positive correlation between test weight and thousand grain weight, while a negative correlation was found between protein ratio and grain yield. Superior lines were marked to enrich the genetic base and were taken into the gen pool as a parents. In addition, the same lines were transferred to advanced yield trials and it was concluded that the breeding processes should be continued by testing them in different environments for at least 3 years.
\end{abstract}

Keywords: Selection, quality, wheat, genotype

\section{GíRiș}

Serin iklim tahıllarından olan buğday, dünyada ve Türkiye'de ekiliş ve üretim miktarı bakımından ilk sırada yer almaya devam etmektedir [1]. Buğday, farklı çevre koşullarına uyum kabiliyetinin yüksek olması ve ekmek yapımında hammadde olarak kullanılması gibi faktörlerden dolayı dünyada ve Türkiye'de Stratejik bir ürün olarak görülmektedir.
Bu sebeple birçok ülkede olduğu gibi ülkemizde de yüksek tane verimi ve kabul edilebilir kalite hedefli buğday ıslah çalışmaları güncelliğini korumaktadır [14]. Güneydoğu Anadolu Bölgesinde farklı çevre koşullarında 1.3 milyon hektar civarında yazlık, alternatif ve kışlık tabiatlı ekmeklik buğday yetiştiriciliği yapılmaktadır [2, 3].

Ekmeklik buğdayın ıslah çalışmalarında protein oranı ile kalite özellikleri arasında önemli düzeyde 
korelasyon mevcut olmakla birlikte protein oranı üzerinde genotip ve çevrenin etkisi büyüktür $[4,5]$. Islah çalışmalarında açılan materyal (F1, F2, F3, F4 vs.) aşamasında araştırma konusu materyallerin tohumu sınırlı miktarda (az) olmaktadır. Bu dönemde materyal 1 metre 1 sira, 1 metre 2 sira veya tek parsele (gözlem nörserisi) ekilmekte ve standart (kontrol) olarak kullanılan çeşitlerle karşılaştırılmaktadır. Tohumu az olan materyalin tekerrürlü olarak ekilmesi mümkün olmadığından dolayı istatistiki olarak karşılaştırma veya yorum yapmak zorlaşmaktadır. Bu sebeple, objektif karşılaştırma yapabilmek için Augmented Deneme Deseni kullanılmaktadır [6]. Augmented Deneme Deseninde kontrol olarak kullanılan çeşitler her blokta bir kez tekrar etmekte ve deneme hatasını hesaplamak mümkün olabilmektedir. Nitekim, blokta bulunan çeşitler ve hatlar ile farklı bloklarda bulunan hatlar karşılaştırılabilmektedir.

Dünya nüfusunun her geçen gün artması insanların gıda ihtiyaçlarının teminini zorlaştırdığından dolayı birim alanda yüksek verimli çeşitlerin tercih edilmesi kaçınılmaz olmuştur. Bu doğrultuda, geliştirilen ıslah yöntemleri ile buğday üretiminin arttırılması ulaşılması istenen hedeflerdendir. $\mathrm{Bu}$ amaçla, bölge koşullarına uyum kabiliyeti yüksek, verim ve kalite açısından ümitvar olan genotipleri belirlemek ve Buğday 1slah programlarına katkı yapmak çalışmanın hedeflerindendir.

Tablo 1. Araştırmada Kullanılan Genotiplere Ait Bilgiler

\section{MATERYAL ve YÖNTEM}

$\mathrm{Bu}$ çalışma, Diyarbakır ekolojisinin yağışa dayalı koşullarında, 2018-2019 yetiştirme sezonunda ve Augmented Deneme Desenine göre GAP Uluslararası Tarımsal Araştırma ve Eğitim Merkezi Müdürlüğü araştırma uygulama alanında yürütülmüştür (Şekil 1). Çalışmada, 120 adet ekmeklik buğday hattı kontrol olarak kullanılan 5 adet tescilli çeşit (kontrol) ile kıyaslanmıştır (Tablo 1). Ayrıca, kontrol çeşitler her blokta tekrar etmiştir. Denemede, parsel uzunluğu 5 $\mathrm{m}$, eni $1.2 \mathrm{~m}$, her parsel $6 \mathrm{sira}$, sira arasi $20 \mathrm{~cm}$ ve hasat döneminde net $6 \mathrm{~m}^{2}$ olacak şekilde oluşturulmuş, ekim 10 Kasım 2018 tarihinde metrekareye 450 tohum düşecek şekilde deneme mibzeri ile yapılmıştır. Dekara saf madde üzerinden $14 \mathrm{~kg}$ azot $(\mathrm{N})$ ve $6 \mathrm{~kg}$ fosfor $\left(\mathrm{P}_{2} \mathrm{O}_{5}\right)$ uygulanmıştır.

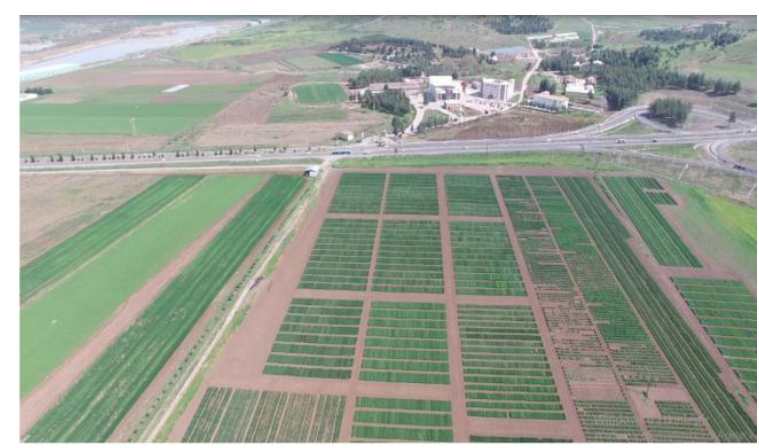

Şekil 1. Deneme Alanına Ait Görüntü

\begin{tabular}{|c|c|c|c|c|c|c|c|}
\hline Genotipler & Pedigri & $\begin{array}{l}\text { Islahçı } \\
\text { kuruluşu } \\
\text { veya } \\
\text { Menşei }\end{array}$ & Tabiatı & Genotipler & Pedigri & $\begin{array}{l}\text { Islahçı } \\
\text { kuruluşu veya } \\
\text { Menşei }\end{array}$ & Tabiatı \\
\hline G1 & $\begin{array}{l}\text { Att1la/3*Bcn*2//Ba } \\
\text { v92/3/Catedral }\end{array}$ & CIMMYT & Yazlık & G61 & $\begin{array}{l}\text { Kachu \#1/Yunma1 } \\
47 / / \text { Kachu/5/Saua } \\
\text { 1/3/ }\end{array}$ & CIMMYT & Yazlık \\
\hline G2 & $\begin{array}{l}\text { Att1la/3*Bcn*2//Ba } \\
\text { v92/3/Catedral }\end{array}$ & CIMMYT & Yazlık & G62 & $\begin{array}{l}\text { Kirıtat1 } / 4 / 2 * \text { Bav } 9 \\
2 / / \text { rena/Kauz/3/H } \\
\text { uite }\end{array}$ & CIMMYT & Yazlık \\
\hline G3 & $\begin{array}{l}\mathrm{Kauz} * 2 / 4 / \mathrm{Car} / / \mathrm{Kal} / \\
\mathrm{Bb} / 3 / \mathrm{Nac} / 5 / \mathrm{Kauz} / 6 / \\
\mathrm{M} 1 \mathrm{lan} / 7\end{array}$ & CIMMYT & Alternatif & G63 & $\begin{array}{l}\mathrm{Kfa} / 2 * \mathrm{Kachu} / 3 / \mathrm{P} \\
\text { bw } 343 * 2 / \mathrm{Kukuna} \\
* 2 / / \mathrm{Fr}\end{array}$ & CIMMYT & Yazlık \\
\hline G4 & $\begin{array}{l}\text { Daphan//Pastor/M1l } \\
\text { an }\end{array}$ & CIMMYT & Yazlık & G64 & $\begin{array}{l}\mathrm{Kfa} / 2 * \mathrm{Kachu}^{*} 2 / / \\
\text { Quelea }\end{array}$ & CIMMYT & Yazlık \\
\hline G5 & $\begin{array}{l}\text { Daphan//Pastor/Mil } \\
\text { an }\end{array}$ & CIMMYT & Yazlık & G65 & $\begin{array}{l}\mathrm{Kfa} / 2 * \mathrm{Kachu}^{*} 2 / / \\
\text { Waxb1 }\end{array}$ & CIMMYT & Yazlık \\
\hline G6 & $\begin{array}{l}\text { F00429gp } 1 / 6 / 53 / 3 / \\
\text { Abl/1113//K92/4/Ja } \\
\mathrm{g} / 5 / \mathrm{Ks} 89\end{array}$ & CIMMYT & Alternatif & G66 & $\begin{array}{l}\text { Wbll1 } * 2 / \text { Brambli } \\
\mathrm{ng} / / \text { Juch1/5/Kıritat } \\
1 / 4\end{array}$ & CIMMYT & Yazlık \\
\hline G7 & $\begin{array}{l}\text { Nudakota/4/Mahon } \\
\text { Demıas/3/Hım/Cndr }\end{array}$ & CIMMYT & Yazlık & G67 & $\begin{array}{l}\text { Achtar*3//Kanz/K } \\
\text { s85-8-5/4/M1lan/ } \\
\text { Kau }\end{array}$ & CIMMYT & Yazlık \\
\hline G8 & $\begin{array}{l}\mathrm{Pvn} / / \mathrm{Car} 422 / \mathrm{Ana} / 5 / \\
\text { Bow/Crow//Buc/Pv } \\
\text { n/ }\end{array}$ & CIMMYT & Alternarif & G68 & $\begin{array}{l}\mathrm{Tc} 870344 / \mathrm{Gu} 1 / \mathrm{T} \\
\text { emporalera M } \\
\text { 87/Agr/ }\end{array}$ & CIMMYT & Yazlık \\
\hline G9 & $\begin{array}{l}\text { Pbw343*2/Kukuna/ } \\
/ \text { Pbw343*2/Kukuna } \\
\text { /3/Ks } 82 \mathrm{w}\end{array}$ & CIMMYT & Yazlık & G69 & $\begin{array}{l}\mathrm{Pbw} 343 / \text { Ton } 1 / \text { Elv } \\
\text { 1ra/7/Cno79//Pf70 } \\
\text { 354/M }\end{array}$ & CIMMYT & Yazlık \\
\hline G10 & $\begin{array}{l}\text { Att1la*2/Pbw65//Ka } \\
\text { chu/3/Up2338*2/K } \\
\text { kts }\end{array}$ & CIMMYT & Yazlık & G70 & Rebwah-13/Zad-2 & ICARDA & Yazlık \\
\hline G11 & $\begin{array}{l}\text { Wbll1*2/Kuruku//H } \\
\text { e1lo/3/Pbw343*2/K } \\
\text { ukuna }\end{array}$ & CIMMYT & Yazlık & G71 & $\begin{array}{l}\text { Qafzah-19//Vee7/ } \\
\text { Kauz }\end{array}$ & ICARDA & Yazlık \\
\hline
\end{tabular}


Tablo 1-Devam

\begin{tabular}{|c|c|c|c|c|c|c|c|}
\hline G12 & $\begin{array}{l}\text { Kachu \#1/Yunma1 } \\
\text { 47//Kachu/5/Saual/ } \\
\text { 3/ }\end{array}$ & CIMMYT & Yazlık & G72 & $\begin{array}{l}\text { Hoosam-8/2*Flag } \\
-4\end{array}$ & ICARDA & Yazlik \\
\hline G13 & $\begin{array}{l}\text { Fret } 2 * 2 / \text { Kukuna//P1 } \\
\text { ha/3/Fret } 2 / \text { Kuruku// } \\
\text { Fret }\end{array}$ & CIMMYT & Yazlık & G73 & $\begin{array}{l}\text { Ser1.1b*2/3/Kauz } \\
* 2 / \mathrm{Bow} / / \mathrm{Kauz}^{*} 2 / \\
\text { 4/Mnc }\end{array}$ & ICARDA & Yazlık \\
\hline G14 & $\begin{array}{l}\text { Fret2/Kukuna//Fret } \\
\text { 2/3/Yanac/4/Fret2/ } \\
\text { Kirita }\end{array}$ & CIMMYT & Yazlık & G74 & $\begin{array}{l}\text { Ser1.1b//Kauz/He } \\
\text { vo/3/Amad/4/Kau } \\
\text { z/Gys }\end{array}$ & ICARDA & Yazlık \\
\hline G15 & $\begin{array}{l}\text { Fret2/Kukuna//Fret } \\
\text { 2/3/Yanac/4/Fret2/ } \\
\text { Kirita }\end{array}$ & CIMMYT & Yazlık & G75 & $\begin{array}{l}\text { Vee/Pjn//2*Kauz/ } \\
\text { 3/Shuha-4/Fow-2 }\end{array}$ & ICARDA & Yazlık \\
\hline G16 & $\begin{array}{l}\text { Fret2/Kukuna//Fret } \\
\text { 2/3/Yanac/4/Fret2/ } \\
\text { Kirita }\end{array}$ & CIMMYT & Yazlık & G76 & $\begin{array}{l}\text { Vee/Nac//Rebwah } \\
-19\end{array}$ & ICARDA & Yazlık \\
\hline G17 & $\begin{array}{l}\text { Trch/Srtu//Kachu*2 } \\
\text { /3/Waxb1 }\end{array}$ & CIMMYT & Yazlık & G77 & $\begin{array}{l}\text { Huw } \\
\text { 234/Rebwah-19 }\end{array}$ & ICARDA & Yazlık \\
\hline G18 & $\begin{array}{l}\text { Trch/Srtu//Kachu*2 } \\
\text { /5/Up2338*2/Sham } \\
\text { a/3/Mila }\end{array}$ & CIMMYT & Yazlık & G78 & $\begin{array}{l}\text { Vee } 7 / \mathrm{Kauz} / 6 / \mathrm{Lfn} / \\
\mathrm{I} 58.57 / / \mathrm{Prl} / 3 / \mathrm{Hah} \\
\text { n/4/ }\end{array}$ & ICARDA & Yazlık \\
\hline G19 & $\begin{array}{l}\text { Trch/Srtu//Kachu*2 } \\
\text { /3/Muu } \\
\text { \#1/Saual//Muu }\end{array}$ & CIMMYT & Yazlık & G79 & $\begin{array}{l}\text { Cham-6/Mubashı1 } \\
\text { r-10 }\end{array}$ & ICARDA & Yazlık \\
\hline G20 & $\begin{array}{l}\text { Trch/Srtu//Kachu*2 } \\
\text { /3/Muu } \\
\text { \#1/Saual//Muu }\end{array}$ & CIMMYT & Yazlık & G80 & $\begin{array}{l}\text { Dajaj-5/4/Chen/A } \\
\text { eg1lops Squarrosa }\end{array}$ & ICARDA & Yazlık \\
\hline G21 & $\begin{array}{l}\text { Bokota*2/3/Up2338 } \\
* 2 / \text { Kkts*2//Yanac }\end{array}$ & CIMMYT & Yazlık & G81 & $\begin{array}{l}\text { Farıs-17//Pfau/M1 } \\
\text { lan }\end{array}$ & ICARDA & Yazlık \\
\hline $\mathrm{G} 22$ & $\begin{array}{l}\text { Up2338*2/Shama/3 } \\
\text { /Milan/Kauz//Ch1l/ } \\
\text { Chum18 }\end{array}$ & CIMMYT & Yazlık & G82 & Cham-8/Ruth-3 & ICARDA & Yazlık \\
\hline $\mathrm{G} 23$ & $\begin{array}{l}\text { Up2338*2/Shama/3 } \\
\text { /Milan/Kauz//Ch1l/ } \\
\text { Chum18/ }\end{array}$ & CIMMYT & Yazlık & G83 & $\begin{array}{l}\text { Trap\#1/Bow//Pfa } \\
\text { u/3/Milan/4/Etbw } \\
\text { 4922/ }\end{array}$ & ICARDA & Yazlık \\
\hline $\mathrm{G} 24$ & $\begin{array}{l}\text { Up2338*2/Shama/3 } \\
\text { /Milan/Kauz//Ch1l }\end{array}$ & CIMMYT & Yazlık & G84 & $\begin{array}{l}\text { Att1la/3*Ben//Mil } \\
\text { an/Ducula }\end{array}$ & ICARDA & Yazlık \\
\hline G25 & $\begin{array}{l}\text { Bav92//Irena/Kauz/ } \\
\text { 3/Huites*2/4/Croc }\end{array}$ & CIMMYT & Yazlık & G85 & $\begin{array}{l}\text { Thelın/Waxwıng// } \\
\text { Attıla*2/Pastor/3 }\end{array}$ & ICARDA & Yazlık \\
\hline G26 & $\begin{array}{l}\text { Att1la*2/Pbw65*2/4 } \\
\text { /Bow/Nkt//Cbrd/3/ } \\
\text { Cbrd/5/P }\end{array}$ & CIMMYT & Yazlık & G86 & $\begin{array}{l}\text { Temporalera M } \\
87 * 2 / \text { Tukuru//Fay } \\
\text { eq-2 }\end{array}$ & ICARDA & Yazlik \\
\hline $\mathrm{G} 27$ & $\begin{array}{l}\text { Att1la*2/Pbw65*2/4 } \\
\text { /Bow/Nkt//Cbrd/3/ } \\
\text { Cbrd/5/ }\end{array}$ & CIMMYT & Yazlık & G87 & $\begin{array}{l}\text { Fayeq-2/3/Nesma } \\
* 2 / 14-2 / / 2 * \text { Safi-3 }\end{array}$ & ICARDA & Yazlık \\
\hline G28 & $\begin{array}{l}\text { Tacupeto } \\
\text { F2001/6/Cndo/R14 } \\
\text { 3//Ente/Mex1_2/3/ }\end{array}$ & CIMMYT & Yazlık & G88 & $\begin{array}{l}\text { Florkwa-2/Njoro } \\
\text { Sd-2/5/Qt6581/4/ } \\
\text { Pasto }\end{array}$ & ICARDA & Yazlık \\
\hline G29 & $\begin{array}{l}\text { Tacupeto } \\
\text { F2001/6/Cndo/R14 } \\
\text { 3//Ente/Mex1_2/3/ }\end{array}$ & CIMMYT & Yazlık & G89 & $\begin{array}{l}\text { Sudan\#3/Shuha-6/ } \\
\text { /Flag-5/3/Pfau/M1 } \\
\text { lan }\end{array}$ & ICARDA & Yazlık \\
\hline G30 & $\begin{array}{l}\text { Tacupeto } \\
\text { F2001/6/Cndo/R14 } \\
\text { 3//Ente/Mex1_2/3/ }\end{array}$ & CIMMYT & Yazlık & G90 & $\begin{array}{l}\text { Attıla } \\
50 y / / \text { Att1la/Bcn/3/ } \\
\text { Kapsw/Shuh }\end{array}$ & ICARDA & Yazlık \\
\hline G31 & $\begin{array}{l}\text { Wbll1*2/Brambling } \\
\text { /4/Babax/Lr42//Bab } \\
\text { ax* }\end{array}$ & CIMMYT & Yazlık & G91 & $\begin{array}{l}\text { Att1la-7/3/Shuha- } \\
\text { 4//Ns732/Her/4/S } \\
\text { oma }\end{array}$ & ICARDA & Yazlık \\
\hline G32 & $\begin{array}{l}\text { Wbll1*2/Bramblıng } \\
\text { /4/Babax/Lr42//Bab } \\
\text { ax*2 }\end{array}$ & CIMMYT & Yazlık & G92 & $\begin{array}{l}\text { Ser1.1b*2/3/Kauz } \\
* 2 / \mathrm{Bow} / / \mathrm{Kauz}^{*} 2 / \\
\text { 4/Mnc }\end{array}$ & ICARDA & Yazlık \\
\hline G33 & $\begin{array}{l}\text { Thelın/2*Wbll1/5/K } \\
\text { auz//Altar } \\
\text { 84/Aos/3/Kauz }\end{array}$ & CIMMYT & Yazlık & G93 & $\begin{array}{l}\text { Shuha-4//Ns732/ } \\
\text { Her/3/Tnmu/Mila } \\
\text { n/4/Bo }\end{array}$ & ICARDA & Yazlık \\
\hline G34 & $\begin{array}{l}\text { Thelın/2*Wbll1/5/K } \\
\text { auz//Altar }\end{array}$ & CIMMYT & Yazlık & G94 & $\begin{array}{l}\text { Kauz//Altar } \\
\text { 84/Aos }\end{array}$ & ICARDA & Yazlık \\
\hline G35 & $\begin{array}{l}\text { 84/Aos/3/Kau } \\
\text { Thelın/2*Wbll1/5/K } \\
\text { auz//Altar } \\
\text { 84/Aos/3/Kauz }\end{array}$ & CIMMYT & Yazlık & G95 & $\begin{array}{l}\text { 3/Kauz/3/Catbird } \\
\text { Dajaj-5/4/Chen/A } \\
\text { egilops Squarrosa }\end{array}$ & ICARDA & Yazlık \\
\hline G36 & $\begin{array}{l}\text { Thelın/2*Wbll1/5/K } \\
\text { auz//Altar } \\
\text { 84/Aos/3/Kau }\end{array}$ & CIMMYT & Yazlık & G96 & $\begin{array}{l}\text { Mex94.27.1.20/3/ } \\
\text { Sokoll//Attıla/3*B } \\
\text { cn/4/ }\end{array}$ & ICARDA & Yazlık \\
\hline G37 & $\begin{array}{l}\mathrm{Kfa} / 5 / \text { Reh/Hare//2* } \\
\mathrm{Bcn} / 3 / \mathrm{Croc} \_1 / \text { Ae.S }\end{array}$ & CIMMYT & Yazlık & G97 & $\begin{array}{l}\text { Debeira//Milan/Pa } \\
\text { stor/4/Ures/Bow// }\end{array}$ & ICARDA & Yazlık \\
\hline
\end{tabular}

$$
\text { G13 }
$$


Araştırma Makalesi/ Research Article

Tablo 1-Devam

\begin{tabular}{|c|c|c|c|c|c|c|c|}
\hline G38 & Kachu/Sup152 & CIMMYT & Yazlık & G98 & $\begin{array}{l}\text { Krichauff/2*Pasto } \\
\text { r//Shuha- } 8\end{array}$ & ICARDA & Yazlık \\
\hline G39 & $\begin{array}{l}\text { Saual/Mutus/4/Kac } \\
\text { hu } \\
\# 1 / / W b 111 * 2 / \text { Kukun }\end{array}$ & CIMMYT & Yazlık & G99 & $\begin{array}{l}\text { Skauz/2*Star/5/Ju } \\
\text { n//Maya/Mon/3/P } \\
\text { go/4 }\end{array}$ & ICARDA & Yazlık \\
\hline G40 & $\begin{array}{l}\text { Saual/Mutus/4/Kac } \\
\text { hu } \\
\# 1 / / \text { Wbll1*2/Kukun } \\
\text { a/3 }\end{array}$ & CIMMYT & Yazlık & G100 & $\begin{array}{l}\text { Pfau/Milan//Fung } \\
\text { Ma1 } \\
\text { 24/3/Attıla*2/ }\end{array}$ & ICARDA & Yazlık \\
\hline G41 & $\begin{array}{l}\text { Pbw343*2/Kukuna } \\
* 2 / / \text { Frt1/Pifed/5/Kac }\end{array}$ & CIMMYT & Yazlık & G101 & $\begin{array}{l}\text { Pfau/Milan//Fung } \\
\text { Ma1 }\end{array}$ & ICARDA & Yazlık \\
\hline G42 & $\begin{array}{l}\text { hu } \\
\text { Bokota/3/Attıla*2/P } \\
\text { bw65//Murga }\end{array}$ & CIMMYT & Yazlık & G102 & $\begin{array}{l}\text { 24/3/Achtar/Inr } \\
\text { Florkwa-2/Njoro } \\
\text { Sd-2/5/Qt6581/4/ } \\
\text { Past }\end{array}$ & ICARDA & Yazlık \\
\hline G43 & $\begin{array}{l}\text { Becard/Akur1/4/Wb } \\
111 * 2 / \text { Bramblıng }\end{array}$ & CIMMYT & Yazlık & G103 & Terbol & ICARDA & Yazlık \\
\hline G44 & $\begin{array}{l}\text { Pbw343*2/Kukuna } \\
* 2 / / \mathrm{Frtl} / \mathrm{P} 1 \mathrm{fed} / 3 / \mathrm{Kfa} \\
/ 2 * \mathrm{Kac}\end{array}$ & CIMMYT & Yazlık & G104 & $\begin{array}{l}\text { Kachu \#1/Yunma } \\
47 / / \text { Kachu/5/Saua } \\
\text { 1/3/ }\end{array}$ & CIMMYT & Yazlık \\
\hline G45 & $\begin{array}{l}\text { Pbw343*2/Kukuna } \\
* 2 / / \mathrm{Frtl} / \mathrm{P} 1 \mathrm{fed} / 3 / \mathrm{Kfa} \\
/ 2 * \mathrm{Kac}\end{array}$ & CIMMYT & Yazlık & G105 & $\begin{array}{l}\text { Francolın } \\
\# 1 / \text { Yanac/5/Kırıta } \\
\text { t1/4/2* }\end{array}$ & CIMMYT & Yazlık \\
\hline G46 & $\begin{array}{l}\text { Pbw343*2/Kukuna } \\
\text { *2//Frt1/P1fed/3/Kfa }\end{array}$ & CIMMYT & Yazlık & G106 & $\begin{array}{l}\text { Whear//2*Prl/2*P } \\
\text { astor/5/Up2338 }\end{array}$ & CIMMYT & Yazlık \\
\hline G47 & $\begin{array}{l}\text { Pbw343*2/Kukuna } \\
* 2 / / \text { Frt1/P1fed/3/Wbl } \\
11 * 2 / \mathrm{Sh}\end{array}$ & CIMMYT & Yazlık & G107 & $\begin{array}{l}\text { Saual/Mutus } / 3 / \mathrm{K}_{1} \\
\text { ngbird \#1//Inqalab } \\
9\end{array}$ & CIMMYT & Yazlık \\
\hline G48 & $\begin{array}{l}\text { Wbll1/4/Bow/Nkt// } \\
\text { Cbrd/3/Cbrd/5/Wbll } \\
1\end{array}$ & CIMMYT & Yazlık & G108 & $\begin{array}{l}\text { Trch/Srtu//Kachu } \\
* 2 / 5 / \mathrm{Up} 2338 * 2 / \mathrm{S} \\
\text { hama }\end{array}$ & CIMMYT & Yazlık \\
\hline G49 & $\begin{array}{l}\text { Mutus*2/Tecue } \\
\# 1 / 3 / \text { Kingbird } \\
\# 1 / / \text { Inqalab } 9\end{array}$ & CIMMYT & Yazlık & G109 & $\begin{array}{l}\text { Saual/4/Croc_1/A } \\
\text { e.Squarrosa } \\
(205) / /\end{array}$ & CIMMYT & Yazlık \\
\hline G50 & $\begin{array}{l}\text { Mucuy//Mutus*2/T } \\
\text { ecue \#1 }\end{array}$ & CIMMYT & Yazlık & G110 & $\begin{array}{l}\text { Saual/Yanac//Sau } \\
\text { al/5/Up2338*2 }\end{array}$ & CIMMYT & Yazlık \\
\hline G51 & $\begin{array}{l}\text { Mucuy/3/Pbw343*2 } \\
\text { /Kukuna*2//Frtl }\end{array}$ & CIMMYT & Yazlık & G111 & $\begin{array}{l}\text { Wbll1*2/Brambli } \\
\text { ng/4/Babax/Lr42// }\end{array}$ & CIMMYT & Yazlık \\
\hline G52 & $\begin{array}{l}\text { Mucuy/4/Att1la*2/P } \\
\text { bw65//Muu } \\
\# 1 / 3 / \text { Franco }\end{array}$ & CIMMYT & Yazlık & G112 & $\begin{array}{l}\text { Thelın/2*Wbll1/5 } \\
\text { /Kauz//Altar } \\
\text { 84/Aos/3 }\end{array}$ & CIMMYT & Yazlık \\
\hline G53 & $\begin{array}{l}\text { Att1la/3*Bcn//Bav9 } \\
\text { 2/3/Pastor/4/Tacupe } \\
\text { to F }\end{array}$ & CIMMYT & Yazlık & G113 & $\begin{array}{l}\text { Waxwing/Kiritatı } \\
* 2 / 3 / \mathrm{C} 80.1 / 3 * \text { Bat } \\
\text { avia/ }\end{array}$ & CIMMYT & Yazlık \\
\hline G54 & $\begin{array}{l}\text { Babax/Lr42//Babax } \\
* 2 / 3 / \text { Kukuna/4/Cros } \\
\text { bill }\end{array}$ & CIMMYT & Yazlık & G114 & $\begin{array}{l}\text { Frncln/Rolf07//Co } \\
\text { p1o/3/Frncln*2/Te } \\
\text { cu }\end{array}$ & CIMMYT & Yazlık \\
\hline G55 & $\begin{array}{l}\text { Att1la*2/Pbw65//Ka } \\
\text { chu*2/3/Francolin } \\
\# 1 / /\end{array}$ & CIMMYT & Yazlık & G115 & $\begin{array}{l}\text { Livingston/6/2*M } \\
\text { trwa92.161/Prınıa } \\
/ 5 / \mathrm{S}\end{array}$ & CIMMYT & Yazlık \\
\hline G56 & $\begin{array}{l}\text { Kauz//Altar } \\
\text { 84/Aos/3/Milan/Ka } \\
\text { uz/4/Saual/5 }\end{array}$ & CIMMYT & Yazlık & G116 & $\begin{array}{l}\text { Sup152/5/Chrz//B } \\
\text { ow/Crow/3/Wbll1 } \\
\text { /4/Cr }\end{array}$ & CIMMYT & Yazlık \\
\hline G57 & $\begin{array}{l}\text { Saual/Mutus*2/3/W } \\
\text { bll1*2/Kuruku//He1l } \\
\text { o }\end{array}$ & CIMMYT & Yazlık & G117 & Kachu/Sup152 & CIMMYT & Yazlık \\
\hline G58 & $\begin{array}{l}\text { Saual/Mutus/3/Att1l } \\
a^{*} 2 / \mathrm{Pbw} 65^{*} 2 / / \text { Kach } \\
\text { u/4/S }\end{array}$ & CIMMYT & Yazlık & G118 & $\begin{array}{l}\text { Waxwıng/7/Tnmu } \\
\text { /6/Cep80111/Cep } \\
81165 / 5 /\end{array}$ & CIMMYT & Alternatif \\
\hline G59 & $\begin{array}{l}\text { Wbll1*2/Kuruku//H } \\
\text { e1lo/3/2*Kachu } \\
\# 1 / \text { Kir }\end{array}$ & CIMMYT & Yazlık & G119 & $\begin{array}{l}\text { Rolf07/Saual/3/Tr } \\
\text { ch/Srtu//Kachu/4/ } \\
\text { Ro }\end{array}$ & CIMMYT & Yazlık \\
\hline G60 & $\begin{array}{l}\text { Wbll1*2/Kuruku//H } \\
\text { e1lo/3/2*Kachu } \\
\# 1 / \text { Kirita }\end{array}$ & CIMMYT & Yazlık & G120 & $\begin{array}{l}\text { Rolf07*2/K1ritat1 } \\
* 2 / / \text { P1caflor \#1 }\end{array}$ & CIMMYT & Yazlık \\
\hline \multicolumn{8}{|c|}{ Kontrol grubu } \\
\hline Dinç & & GAPUTAEM & & Yazlık & & & \\
\hline Pehlivan & & TTAEM & & Kışlık & & & \\
\hline Esperia & & TASACO & & Kışlık & & & \\
\hline Tekin & & GAPUTAEM & & Yazlık & & & \\
\hline Ceyhan-99 & & DATAE & & Yazlık & & & \\
\hline
\end{tabular}


Araştırmada, saf azotun 6 kg’1 ekimle birlikte, kalan miktarı ise bitkilerin Zadoks 25 [7] aşamasında olduğu dönemde, fosforun ise tamamı ekimle birlikte uygulanmıştır. Hasat işlemi Haziran ayının ikinci haftasında parsel biçerdöveri ile gerçekleştirilmiştir. Denemenin kurulduğu sezonda gerçekleșen yağıș ile ilgili değerler genel olarak bütün dönemlerde değişkenlik göstermiştir.

Tablo 2. Diyarbakır İlinin 2018-2019 İklim Verileri

\begin{tabular}{|c|c|c|c|c|c|c|}
\hline \multirow{2}{*}{ Aylar } & \multicolumn{3}{|c|}{ Yağıș Miktarı (mm) } & \multicolumn{3}{|c|}{ 2018-2019 Sıcaklık Değerleri $\left({ }^{\circ} \mathrm{C}\right)$} \\
\hline & 2018-2019 & UYO & Minimum & Maksimum & Ortalama & UYO \\
\hline Eylül & 6.2 & 9.1 & 17.3 & 34.6 & 26.0 & 24.8 \\
\hline Ekim & 76.6 & 33.1 & 12.4 & 25.8 & 19.1 & 17.4 \\
\hline Kasım & 88.2 & 48.9 & 5.7 & 15.5 & 10.6 & 9.8 \\
\hline Aralık & 190.8 & 70.2 & 3.1 & 9.9 & 6.5 & 4.3 \\
\hline Ocak & 67.6 & 62.7 & 0.1 & 7.8 & 4.0 & 1.8 \\
\hline Şubat & 77.4 & 63.6 & 0.4 & 10.9 & 5.7 & 3.8 \\
\hline Mart & 135.2 & 70.9 & 3.1 & 13.7 & 8.4 & 9.5 \\
\hline Nisan & 152.6 & 64.1 & 5.8 & 17.8 & 11.8 & 13.9 \\
\hline Mayıs & 45.8 & 47 & 11.1 & 28.3 & 19.7 & 19.3 \\
\hline Haziran & 0 & 10 & 17.8 & 35.4 & 26.6 & 26.6 \\
\hline Toplam & 840.4 & 479.6 & - & - & - & - \\
\hline Ortalama & - & - & - & - & 13.8 & 13.12 \\
\hline
\end{tabular}

*Diyarbakır Meteoroloji Bölge Müdürlüğ̈’’nün yıllık iklim rasatlarından alınmıştır. UYO: Uzun yıllar ortalaması

Tablo 2'de görüldüğü gibi özellikle Ekim, Kasım, Aralık, Mart ve Nisan aylarında kaydedilen yağışlar uzun yıllar ortalamasına göre sapma göstermiştir. Ayrıca, tabloda görüldüğü üzere buğdayın suya ihtiyaç duyduğu dönemlerde gerçekleşen yağış miktarı uzun yıllar ortalamasının üzerinde olmuştur. Yeterli yağış miktarının gerçekleşmesi verim potansiyeline bağlı olarak bazı genotiplerin tane verimine olumlu olarak yansımıştır. Ortalama sıcaklık verileri incelendiğinde ise uzun yıllarınortalamasına yakın değerlerin olduğu ve kaydedilen verilerin uzun y1llara ait ortalama değerlerden önemli bir sapma göstermediği görülmüştür. Toprak analizi sonuçları incelendiğinde deneme alanı topraklarının killi olduğu, reaksiyon olarak hafif alkali karakterli ve organik madde miktarı bakımından fakir olduğu söylenebilir. Toprağın içerdiği makro besin elementlerinin miktarlarına bakıldığında ise $\mathrm{P}_{2} \mathrm{O}_{5}$ miktarının çok düşük, $\mathrm{K}_{2} \mathrm{O}$ (potasyum) miktarının ise orta sınıfta olduğu görülmektedir (Tablo 3).

Tablo 3. Deneme Yeri Toprağının Bazı Fiziksel ve Kimyasal Özellikleri

\begin{tabular}{lllllllll}
\hline $\begin{array}{l}\text { Tekstür } \\
\text { smnfı }\end{array}$ & $\begin{array}{l}\text { Derinlik } \\
(\mathbf{c m})\end{array}$ & $\begin{array}{l}\text { Organik } \\
\text { madde } \\
(\boldsymbol{\%})\end{array}$ & $\begin{array}{l}\mathbf{C a C O 3} \\
(\boldsymbol{\%})\end{array}$ & $\begin{array}{l}\mathbf{P}_{2} \mathbf{O}_{5} \\
\left(\mathbf{k g ~ d a}^{-1}\right)\end{array}$ & $\begin{array}{l}\mathbf{K}_{2} \mathbf{O} \\
\left(\mathbf{k g d}^{-1}\right)\end{array}$ & $\begin{array}{l}\text { Toplam tuz } \\
(\%)\end{array}$ & $\begin{array}{l}\text { Su ile } \\
\text { doygunluk } \\
(\boldsymbol{\%})\end{array}$ & $\mathbf{p H}$ \\
\hline Killi & $0-30$ & 0.96 & 7.31 & 1.49 & 94.38 & 0.023 & 72.5 & 8.15 \\
\hline
\end{tabular}

\section{İncelenen Özellikler}

Araştırmada, tane verimi için parselin tamamı hasat edildikten sonra birim alandan elde edilen verim miktarı $\mathrm{kg} \mathrm{da}^{-1}$ dönüştürülerek belirlenmiştir. Bin tane ağırlığını belirlemek için öncelikle 400 tane sayılıp g cinsinden ağırlığı belirlenmiş ardından elde edilen değer 2.5 ile çarpılarak 1000 tane ağırlığ tespit edilmiştir. Hektolitre ağırlı̆̆ını ve protein oranını belirlemek amaciyla NIT spectometre cihazı kullanılmıştır. Elde edilen verilerin varyans analizleri JMP 13.0 pro paket programı kullanılarak yapılmıştır. Önemli ( $\leq 0.01$ veya $p \leq 0.05$ göre ) bulunan özelliklerin ortalamaları Tukey testi ile gruplandırılmıştır. Ayrıca özellikler arasındaki ilişkilerin görsel sunumu için Genstat $12^{\text {th }}$ paket programı kullanılmış ve elde edilen sonuçlar doğrultusunda oluşturulan GGE biplot grafiği yorumlanmıştır.

\section{BULGULAR ve TARTIȘMA}

Varyans analizi sonuçlarına göre; çeşitler arasında incelenen özellikler bakımından istatistiki olarak önemli ( $\mathrm{P}<0.01$ ve $\mathrm{P}<0.05)$ farklılıklar görülmüştür (Tablo 4). Her bir özellik için çeşitler arasında oluşan farklılıklar Tukey testine göre değerlendirilmiştir. Çalışmada özellikle kalite parametrelerinde birçok hattın incelenen özellikler yönünden kontrol çeşitlerden üstün olduğu belirlenmiştir (Tablo 5). 
Araştırma Makalesi/ Research Article

Tablo 4. Kareler Ortalamasına Ait Varyans Analiz Tablosu

\begin{tabular}{llllll}
\hline Varyans Kaynakları & SD & TV & HL & BTA & PRT \\
\hline Model & 129 & 7570.22 & 2.78 & 10.23 & 0.60 \\
Blok & 5 & 2315.96 & 0.22 & 1.88 & 0.1 \\
Genotip & 124 & $7253.02^{*}$ & $2.83^{* *}$ & $9.76^{* *}$ & $0.59^{* *}$ \\
Hata & 20 & 2958.78 & 0.17 & 1.68 & 0.06 \\
\hline $\mathrm{T}(0.05)$ & & 439.56 & 3.35 & 10.49 & 1.97 \\
\hline $\mathrm{DK}(\%)$ & 9.04 & 0.51 & 3.54 & 2.43 \\
\hline
\end{tabular}

* 0.05, ** 0.01 düzeyinde önemli, DK: Değişim Katsayısı, SD: Serbestlik Derecesi, TV: Tane Verimi, HL: Hektolitre ağırlı̆̆ı, BTA: Bin tane Ağırlığı, PRT: Protein Oranı

Tablo 5. İncelenen Özellikler Bakımından Genotiplerden Elde Edilen Değerler ve Oluşan Gruplar

\begin{tabular}{|c|c|c|c|c|}
\hline Genotip (G) & Tane verimi $\left(\mathrm{kg} \mathrm{da}^{-1}\right)$ & Hektolitre (kg hl-1) & Bin tane (g) & Protein (\%) \\
\hline G1 & $415.8 \mathrm{ab}$ & $79.39 \mathrm{x}-\mathrm{d} 1$ & $34.55 b-n$ & $9.91 \mathrm{f}-\mathrm{e} 1$ \\
\hline $\mathrm{G} 2$ & $462.2 \mathrm{ab}$ & 80.49 q-d1 & 36.15 b-n & $10.01 \mathrm{c}-\mathrm{e} 1$ \\
\hline G3 & $440.5 \mathrm{ab}$ & $80.59 \mathrm{o}-\mathrm{d} 1$ & $36.15 b-n$ & $10.01 \mathrm{c}-\mathrm{e} 1$ \\
\hline G4 & $490.8 \mathrm{ab}$ & $81.56 \mathrm{c}-\mathrm{b} 1$ & 37.75 a-n & $10.71 \mathrm{~b}-\mathrm{d} 1$ \\
\hline G5 & $515.0 \mathrm{ab}$ & 82.19 a-x & 38.35 a-n & $10.11 \mathrm{~b}-\mathrm{d} 1$ \\
\hline G6 & $465.8 \mathrm{ab}$ & 83.89 a-p & $37.95 \mathrm{a}-\mathrm{n}$ & $9.91 \mathrm{f}-\mathrm{e} 1$ \\
\hline G7 & $582.8 \mathrm{ab}$ & $80.891-\mathrm{c} 1$ & $31.751-\mathrm{m}$ & $9.31 \mathrm{~m}-\mathrm{e} 1$ \\
\hline G8 & $597.8 \mathrm{ab}$ & $81.79 \mathrm{a}-\mathrm{b} 1$ & 34.95 b-n & $10.21 \mathrm{~b}-\mathrm{e} 1$ \\
\hline G9 & $625.2 \mathrm{ab}$ & $79.09 \mathrm{y}-\mathrm{d} 1$ & $33.75 \mathrm{c}-\mathrm{n}$ & $10.01 \mathrm{c}-\mathrm{e} 1$ \\
\hline G10 & $680.5 \mathrm{a}$ & $81.19 \mathrm{e}-\mathrm{c} 1$ & $35.95 b-n$ & $10.31 \mathrm{~b}-\mathrm{e} 1$ \\
\hline G11 & $617.5 \mathrm{ab}$ & $82.09 \mathrm{a}-\mathrm{z}$ & $35.95 \mathrm{~b}-\mathrm{n}$ & $11.71 \mathrm{a}-\mathrm{g}$ \\
\hline G12 & $648.5 \mathrm{a}$ & $81.29 \mathrm{c}-\mathrm{b} 1$ & $37.55 \mathrm{a}-\mathrm{n}$ & $11.01 \mathrm{a}-\mathrm{d} 1$ \\
\hline G13 & $425.0 \mathrm{ab}$ & 83.89 a-p & $35.35 \mathrm{~b}-\mathrm{n}$ & $12.61 \mathrm{a}$ \\
\hline G14 & $549.2 \mathrm{ab}$ & $83.19 \mathrm{a}-\mathrm{t}$ & $34.75 \mathrm{~b}-\mathrm{n}$ & $9.21 \mathrm{q}-\mathrm{e} 1$ \\
\hline G15 & $541.5 \mathrm{ab}$ & $82.89 \mathrm{a}-\mathrm{v}$ & $34.95 \mathrm{~b}-\mathrm{n}$ & $9.31 \mathrm{~m}-\mathrm{e} 1$ \\
\hline G16 & $538.3 \mathrm{ab}$ & 84.69 a-d & 37.15 a-n & $9.91 \mathrm{f}-\mathrm{e} 1$ \\
\hline G17 & $645.5 \mathrm{a}$ & $83.19 \mathrm{a}-\mathrm{t}$ & $41.55 \mathrm{a}-\mathrm{n}$ & $9.61 \mathrm{~h}-\mathrm{e} 1$ \\
\hline G18 & $646.3 \mathrm{a}$ & 82.79 a-w & 37.35 a-n & $9.91 \mathrm{f}-\mathrm{e} 1$ \\
\hline G19 & $695.3 \mathrm{a}$ & 81.89 a-b1 & $36.95 \mathrm{a}-\mathrm{n}$ & $10.01 \mathrm{c}-\mathrm{e} 1$ \\
\hline $\mathrm{G} 20$ & $647.0 \mathrm{a}$ & 81.99 a-b1 & 38.15 a-n & $9.11 \mathrm{q}-\mathrm{e} 1$ \\
\hline G21 & $670.1 \mathrm{a}$ & $83.71 \mathrm{a}-\mathrm{r}$ & 39.51 a-n & 9.79 e-e1 \\
\hline $\mathrm{G} 22$ & $186.3 \mathrm{ab}$ & $82.81 \mathrm{a}-\mathrm{w}$ & $38.11 \mathrm{a}-\mathrm{n}$ & $10.19 \mathrm{~b}-\mathrm{e} 1$ \\
\hline $\mathrm{G} 23$ & 813.0 a & $83.11 \mathrm{a}-\mathrm{t}$ & 37.51 a-n & $9.491-\mathrm{e} 1$ \\
\hline $\mathrm{G} 24$ & $708.6 \mathrm{a}$ & $82.81 \mathrm{a}-\mathrm{w}$ & 38.31 a-n & $10.49 \mathrm{~b}-\mathrm{e} 1$ \\
\hline G25 & $665.3 \mathrm{a}$ & 84.51 a-f & 38.71 a-n & 9.69 h-e1 \\
\hline $\mathrm{G} 26$ & $573.0 \mathrm{ab}$ & 82.31 a-y & 38.51 a-n & 9.49 1-e1 \\
\hline G27 & $649.0 \mathrm{a}$ & $83.11 \mathrm{a}-\mathrm{t}$ & $36.11 \mathrm{~b}-\mathrm{n}$ & 8.99 r-e1 \\
\hline G28 & $570.0 \mathrm{ab}$ & $84.01 \mathrm{a}-\mathrm{m}$ & 39.71 a-n & 9.79 e-e1 \\
\hline $\mathrm{G} 29$ & $642.1 \mathrm{a}$ & 84.91 a & 39.51 a-n & $10.39 \mathrm{~b}-\mathrm{e} 1$ \\
\hline G30 & $658.3 \mathrm{a}$ & 81.71 b-b1 & 38.11 a-n & $10.49 \mathrm{~b}-\mathrm{e} 1$ \\
\hline G31 & $706.8 \mathrm{a}$ & $82.51 \mathrm{a}-\mathrm{x}$ & $33.51 \mathrm{c}-\mathrm{n}$ & 9.69 h-e1 \\
\hline G32 & $749.8 \mathrm{a}$ & 82.41 a-y & $35.11 \mathrm{~b}-\mathrm{n}$ & $10.09 \mathrm{c}-\mathrm{e} 1$ \\
\hline G33 & $654.3 \mathrm{a}$ & $82.91 \mathrm{a}-\mathrm{V}$ & $35.51 \mathrm{~b}-\mathrm{n}$ & 9.59 h-e1 \\
\hline G34 & $683.8 \mathrm{a}$ & 82.31 a-y & 36.11 b-n & 9.09 g-e1 \\
\hline G35 & $659.8 \mathrm{a}$ & 82.71 a-X & $37.11 \mathrm{a}-\mathrm{n}$ & $9.19 \mathrm{p}$-e1 \\
\hline G36 & $663.5 \mathrm{a}$ & $82.61 \mathrm{a}-\mathrm{x}$ & $35.71 \mathrm{~b}-\mathrm{n}$ & $9.29 \mathrm{~m}-\mathrm{e} 1$ \\
\hline G37 & $549.5 \mathrm{ab}$ & 83.11 a-t & $33.31 \mathrm{~d}-\mathrm{n}$ & 9.99 e-e1 \\
\hline G38 & $576.3 \mathrm{ab}$ & $82.01 \mathrm{a}-\mathrm{b} 1$ & 35.31 b-n & 9.69 h-e1 \\
\hline G39 & $525.3 \mathrm{ab}$ & $82.11 \mathrm{a}-\mathrm{z}$ & $23.51 \mathrm{~m}$ & $10.19 \mathrm{~b}-\mathrm{e} 1$ \\
\hline G40 & $538.0 \mathrm{ab}$ & $84.11 \mathrm{a}-\mathrm{k}$ & 36.71 a-n & $10.79 \mathrm{a}-\mathrm{d} 1$ \\
\hline G41 & $486.8 \mathrm{ab}$ & $82.47 \mathrm{a}-\mathrm{x}$ & 37.55 a-n & 9.47 j-e1 \\
\hline G42 & $547.0 \mathrm{ab}$ & $81.27 \mathrm{f}-\mathrm{b} 1$ & 39.35 a-n & $9.37 \mathrm{k}-\mathrm{e} 1$ \\
\hline G43 & $566.5 \mathrm{ab}$ & $79.57 \mathrm{u}-\mathrm{d} 1$ & 35.15 b-n & $9.77 \mathrm{~g}$-e1 \\
\hline G44 & $475.3 \mathrm{ab}$ & $84.27 \mathrm{a}-\mathrm{h}$ & 39.95 a-n & $11.57 \mathrm{a}-\mathrm{a} 1$ \\
\hline G45 & $494.2 \mathrm{ab}$ & $84.17 \mathrm{a}-1$ & 39.35 a-n & $11.47 \mathrm{a}-\mathrm{b} 1$ \\
\hline G46 & $477.5 \mathrm{ab}$ & 83.67 a-r & $42.35 \mathrm{a}-\mathrm{f}$ & 11.97 abc \\
\hline G47 & $692.5 \mathrm{a}$ & 81.37 b-b1 & 36.35 a-n & 8.67 w-e1 \\
\hline G48 & $530.7 \mathrm{ab}$ & $81.57 \mathrm{a}-\mathrm{b} 1$ & 43.35 a-d & $11.37 \mathrm{a}-\mathrm{b} 1$ \\
\hline G49 & $586.7 \mathrm{ab}$ & $80.67 \mathrm{~m}-\mathrm{d} 1$ & 35.55 b-n & $10.77 \mathrm{a}-\mathrm{d} 1$ \\
\hline G50 & $693.3 \mathrm{a}$ & 83.77 a-r & 39.35 a-n & $10.67 \mathrm{ad} 1$ \\
\hline G51 & $681.2 \mathrm{a}$ & $83.27 \mathrm{a}-\mathrm{t}$ & $34.75 c-n$ & $10.77 \mathrm{a}-\mathrm{d} 1$ \\
\hline G52 & $673.2 \mathrm{a}$ & $79.57 \mathrm{u}-\mathrm{d} 1$ & $33.75 \mathrm{e}-\mathrm{n}$ & $10.27 \mathrm{~b}-\mathrm{e} 1$ \\
\hline G53 & $578.7 \mathrm{ab}$ & 84.37 a-e & 40.35 a-n & 11.67 a-y \\
\hline
\end{tabular}


Araştırma Makalesi/ Research Article

\section{Tablo 5-Devam}

\section{G54}

G55

G56

G57

G58

G59

G60

G61

G63

G64

G65

G66

G67

G68

G69

G70

G71

G73

G74

G75

G76

G77

G78

G79

G81

G82

G83

G84

G85

G86

G87

G88

G89

G90

G91

G92

G93

G94

G95

G96

G97

G98

G99

G100

G101

G102

G103

G104

G105

G106

G107

G108

G109

G110

G111

G112

G113

G114

G115

G116

G117
$625.0 \mathrm{ab}$

$614.7 \mathrm{ab}$

$601.5 \mathrm{ab}$

$669.0 \mathrm{a}$

$681.5 \mathrm{a}$

$655.8 \mathrm{a}$

$656.2 \mathrm{a}$

$572.2 \mathrm{ab}$

$478.5 \mathrm{ab}$

$477.0 \mathrm{ab}$

$647.2 \mathrm{ab}$

$626.4 \mathrm{a}$

$571.4 \mathrm{ab}$

$660.0 \mathrm{a}$

$657.2 \mathrm{a}$

$583.7 \mathrm{ab}$

$516.5 \mathrm{ab}$

745.5 a

$668.4 \mathrm{a}$

$644.7 \mathrm{a}$

$635.2 \mathrm{a}$

$539.9 \mathrm{ab}$

$618.0 \mathrm{ab}$

$622.7 \mathrm{ab}$

$592.7 \mathrm{ab}$

$525.2 \mathrm{ab}$

$512.7 \mathrm{ab}$

$527.7 \mathrm{ab}$

$503.5 \mathrm{ab}$

$571.9 \mathrm{ab}$

$636.7 \mathrm{a}$

$612.5 \mathrm{ab}$

$691.2 \mathrm{a}$

$657.7 \mathrm{a}$

641.7 a

$669.4 \mathrm{a}$

$633.7 \mathrm{a}$

666.7 a

$589.5 \mathrm{ab}$

$578.7 \mathrm{ab}$

$578.5 \mathrm{ab}$

$529.4 \mathrm{ab}$

$587.4 \mathrm{ab}$

654.5 a

$591.9 \mathrm{ab}$

$688.0 \mathrm{a}$

$643.0 \mathrm{a}$

749.9 a

666.6 a

$677.1 \mathrm{a}$

$710.6 \mathrm{a}$

$601.2 \mathrm{ab}$

656.7 a

$575.6 \mathrm{ab}$

$478.4 \mathrm{ab}$

$593.6 \mathrm{ab}$

$568.7 \mathrm{ab}$

$687.2 \mathrm{a}$

$734.7 \mathrm{a}$

737.6 a

638.2 a

$704.6 \mathrm{a}$

$631.2 \mathrm{a}$

$556.1 \mathrm{ab}$
81.97 a-a1

84.27 a-h

81.57 a-b1

78.67 b1-e1

80.57 p-d1

82.47 a-x

82.47 a-x

81.31 e-b1

83.31 a-s

$80.81 \mathrm{j}-\mathrm{c} 1$

81.61 a-b1

84.21 a-1

83.41 a-s

82.01 a-b1

76.01 e 1

82.61 a-x

$78.81 \mathrm{z}-\mathrm{e} 1$

81.41 d-b1

$81.01 \mathrm{~g}-\mathrm{c} 1$

82.31 a-y

$79.61 \mathrm{v}-\mathrm{d} 1$

80.11 t-d1

84.61 a-f

82.41 a-y

82.41 a-y

83.41 a-s

82.91 a-u

80.93 h-c 1

77.33 d1-e

80.63 n-c1

81.83 a-b1

81.73 a-b1

83.33 a-t

$83.03 \mathrm{a}-\mathrm{t}$

$83.83 \mathrm{a}-\mathrm{q}$

80.43 r-c1

$82.13 \mathrm{a}-\mathrm{z}$

81.43 b-b1

82.23 a-y

83.73 a-q

81.33 c-b1

$83.03 \mathrm{a}-\mathrm{t}$

$82.03 \mathrm{a}-\mathrm{z}$

83.83 a-q

82.43 a-y

82.23 a-y

$83.13 \mathrm{a}-\mathrm{t}$

81.67 a-b1

83.87 a-p

82.17 a-y

81.57 a-b1

81.77 a-b1

83.57 a-r

81.87 a-b1

82.57 a-x

82.67 a-x

81.27 c-b1

84.17 a-1

82.67 a-x

83.47 a-r

$82.87 \mathrm{a}-\mathrm{v}$

80.27 s-d1

80.77 k-c1

81.67 a-b1
39.35 a-n

$35.15 \mathrm{~b}-\mathrm{n}$

38.35 a-n

37.75 a-n

$41.35 \mathrm{a}-\mathrm{n}$

44.55 ab

40.15 a-n

37.11 a-n

35.11 b-n

39.71 a-n

40.31 a-n

42.71 a-f

37.91 a-n

35.31 b-n

$39.91 \mathrm{a}-\mathrm{n}$

$37.51 \mathrm{a}-\mathrm{n}$

$35.11 \mathrm{~b}-\mathrm{n}$

36.71 a-n

34.11 b-n

$33.91 \mathrm{c}-\mathrm{n}$

$33.51 \mathrm{c}-\mathrm{n}$

40.11 a-n

38.71 a-n

$36.11 \mathrm{~b}-\mathrm{n}$

$31.31 \mathrm{~h}-\mathrm{m}$

36.51 a-n

$36.91 \mathrm{a}-\mathrm{n}$

34.35 b-n

$29.35 \mathrm{~lm}$

$38.55 \mathrm{a}-\mathrm{n}$

$32.75 \mathrm{f}-\mathrm{n}$

37.75 a-n

$38.55 \mathrm{a}-\mathrm{n}$

$32.55 \mathrm{f}-\mathrm{n}$

$34.55 \mathrm{~b}-\mathrm{n}$

$34.55 \mathrm{~b}-\mathrm{n}$

$33.55 \mathrm{c}-\mathrm{n}$

$37.35 \mathrm{a}-\mathrm{n}$

$31.95 \mathrm{~g}-\mathrm{n}$

$34.55 \mathrm{~b}-\mathrm{n}$

$30.95 \mathrm{j}-\mathrm{m}$

35.95 b-n

38.55 a-n

$37.35 \mathrm{a}-\mathrm{n}$

$37.15 \mathrm{a}-\mathrm{n}$

35.15 b-n

35.55 b-n

$34.91 \mathrm{~b}-\mathrm{n}$

35.91 b-n

36.11 b-n

39.11 a-n

40.91 a-n

$39.71 \mathrm{a}-\mathrm{n}$

43.91 a-e

37.71 a-n

46.71 a

$37.31 \mathrm{a}-\mathrm{n}$

35.91 b-n

36.31 b-n

34.71 b-n

$42.11 \mathrm{a}-\mathrm{n}$

$41.11 \mathrm{a}-\mathrm{n}$

36.51 b-n

33.91 d-n

9.17 p-e1

9.27o-e1

9.27 o-e1

9.77 g-e1

10.17 d-e 1

11.17 a-b1

$10.67 \mathrm{a}-\mathrm{d} 1$

9.97 e-e 1

10.47 b-e 1

12.07 a-d

$10.27 \mathrm{c}-\mathrm{e} 1$

9.87 e-e 1

$9.37 \mathrm{j}$-e1

$9.37 \mathrm{j}$-e1

9.07 s-e 1

10.77 a-d 1

10.17 c-e 1

9.67 h-e1

$10.87 \mathrm{a}-\mathrm{d} 1$

9.97 e-e 1

10.17 c-e1

$9.07 \mathrm{~s}-\mathrm{e} 1$

$10.07 \mathrm{c}-\mathrm{e} 1$

$9.07 \mathrm{~s}-\mathrm{e} 1$

$10.57 \mathrm{~b}-\mathrm{e} 1$

10.87 a-d 1

$9.67 \mathrm{~h}-\mathrm{e} 1$

9.83 e-e 1

10.33 b-e 1

$11.13 \mathrm{a}-\mathrm{b} 1$

$9.63 \mathrm{~h}-\mathrm{e} 1$ 


\begin{tabular}{lllll} 
Tablo 5-Devam & & & & \\
G118 & $569.6 \mathrm{ab}$ & $82.67 \mathrm{a}-\mathrm{x}$ & $39.31 \mathrm{a}-\mathrm{n}$ & $9.63 \mathrm{~h}-\mathrm{e} 1$ \\
$\mathrm{G} 119$ & $625.7 \mathrm{ab}$ & $83.37 \mathrm{a}-\mathrm{t}$ & $38.11 \mathrm{a}-\mathrm{n}$ & $10.43 \mathrm{~b}$-e1 \\
G120 & $437.7 \mathrm{ab}$ & $77.87 \mathrm{c} 1-\mathrm{e} 1$ & $37.51 \mathrm{a}-\mathrm{n}$ & $11.13 \mathrm{a}-\mathrm{b} 1$ \\
\hline Dinç & $624.2 \mathrm{a}$ & $83.10 \mathrm{a}-\mathrm{n}$ & $34.50 \mathrm{gl}$ & $9.50 \mathrm{q}$-e1 \\
Pehlivan & $594.9 \mathrm{a}$ & $80.35 \mathrm{w}-\mathrm{c} 1$ & $36.13 \mathrm{c}-\mathrm{n}$ & $9.30 \mathrm{u}-\mathrm{e} 1$ \\
Esperia & $532.3 \mathrm{a}$ & $81.52 \mathrm{l}-\mathrm{y}$ & $32.70 \mathrm{kl}$ & $10.52 \mathrm{c}-\mathrm{d} 1$ \\
Tekin & $627.3 \mathrm{a}$ & $83.47 \mathrm{a}-\mathrm{g}$ & $38.73 \mathrm{~b}-\mathrm{n}$ & $9.32 \mathrm{t}$-e 1 \\
Ceyhan-99 & $588.9 \mathrm{a}$ & $79.53 \mathrm{a} 1-\mathrm{d} 1$ & $34.10 \mathrm{hkl}$ & $10.02 \mathrm{~h}$-e 1 \\
\hline Ortalama & 603.0 & 82.13 & 36.89 & 10.01 \\
\hline Minimum & 186.3 & 76.01 & 23.51 & 8.67 \\
\hline Maksimum & 813.0 & 84.91 & 46.71 & 12.61 \\
\hline En yüksek kontrolden & - & 5 & 66 & 46 \\
\hline daha üstün hat sayls1 & - & &
\end{tabular}

Not: Bold olarak yazılan değerler ilgili özellik bakımından en iyi olan hatlara ait değerleri göstermektedir.

\section{Tane Verimi ve Hektolitre A $\breve{g}$ lrllı̆gl}

Çalışmada genotipler arasında tane verimi bakımından $\% 5$, hektolitre ağırlığında \%1 düzeyinde önemli farklılıklar olduğu belirlenmiştir (Tablo 4). Genotiplerin tane verimi potansiyeli, birçok tarımsal karakterin doğrudan veya dolaylı olarak etkisi altında oluşan, tarımsal karakterlerin bileşkesi olarak tanımlanabilecek bir özelliktir. Diyarbakır koşullarında ekmeklik buğdayda yapılan bir çalışmada, tane veriminin 514.5-820.9 $\mathrm{kg} \mathrm{da} \mathrm{da}^{-1}$ arasında değiştiği bildirilmiştir. Ayrıca, tane veriminin çalışmanın yapıldığı ekoloji, genotiplerin kalıtımı ve agronomik uygulamaların etkileşiminin bileşkesi olduğu vurgulanmıştır. Oransal olarak tane verimi potansiyelinde genetik faktörlerin belirleyici olduğu bildirilmiştir [8, 9, 10] . Çalışmada G23 (813.0 $\left.\mathrm{kg} \mathrm{da}^{-1}\right), \mathrm{G} 32$ (749.8 $\left.\mathrm{kg} \mathrm{da}^{-1}\right), \mathrm{G} 71$ (745.5 kg da $\left.{ }^{-1}\right), \mathrm{G} 101$ $\left(749.9 \mathrm{~kg} \mathrm{da}^{-1}\right)$ ve G113 (737.6 $\left.\mathrm{kg} \mathrm{da}^{-1}\right)$ 'ün tane verimi yönünden en iyi hatlar olduğu görülmüştür.

Diyarbakır koşullarında yapılan başka bir ekmeklik buğday çalışmasında Augmented Deneme Desenine göre tane veriminin $354.51-810.77 \mathrm{~kg} \mathrm{da}^{-1}$, hektolitre ağırlığının 77.46- $82.10 \mathrm{~kg} \mathrm{hl}^{-1}$ aralığında farklılık gösterdiği bildirilmiştir [11]. Isparta ve Bingöl koşullarında ekmeklik buğdayda yapılan bir çalışmada hektolitre ağırlığı için sırasıyla; 76.0-82.0 $\mathrm{kg} \mathrm{hl}^{-1}$ ve 76.4-81.4 $\mathrm{kg} \mathrm{hl}^{-1}$ değerlerinin elde edildiği bildirilmiştir [12, 13]. Bu çalışmada hektolitre ağırlığının 76.01-84.91 kg hl${ }^{-1}$ arasında değişim göstermesi araştırmada kullanılan genotipler arasında geniş bir varyasyonun olduğunu göstermektedir. Bu yönüyle elde edilen sonuçlar benzer değildir.

\section{Bin Tane A}

Bin tane ağırlığı tane verimi üzerinde etkili olan önemli teknolojik kalite parametrelerinden biridir. Bin tane ağırlığının üretim sezonu içerisinde verim ve verim komponentlerinin (başak uzunluğu, başak ağırlığı, başaktaki başakçık ve tane sayısı, metrekaredeki başak sayısı vs.) birbiriyle rekabetinden etkilenen bir özellik olduğu, Aydın İlinde ekmeklik buğdayda 2 yıl süren bir çalışmada bin tane ağırlığı ortalamasının 22.1-42.0 g arasında değişkenlik gösterdiği bildirilmiştir [14]. Bu çalışma, bin tane ağırlığı bakımından elde edilen 23.51-46.71 g aralığındaki geniş varyasyon değerleri ile farklılık göstermiştir. Daha yüksek değerlerin elde edilmesi çalışmaların yapıldığı ekolojik koşulların farklılığından kaynaklandığı düşünülmektedir. Buğdayın işleneceği ürün grubunu belirlemede tane protein içeriği büyük bir önem teşkil etmektedir. İnsan beslenmesinde büyük bir önemi olan proteinler insan vücudunda yapıcı ve onarıc1 rolünü üstlendiğinden dolayı buğday tanesindeki protein oranı değerlidir. Tane protein oranı \%6-22 arasında geniş bir rence sahiptir. $\mathrm{Bu}$ durum protein oranının genetik faktörler ile beraber önemli ölçüde çevre koşullarından etkilenmesinden kaynaklanmaktadır $[15,16]$. Genotip sayısı (120 hat ve 5 çeşit) oldukça fazla olan bu çalışmada protein oranının \%8.67-12.61 arasında değişim gösterdiği belirlenmiştir.

\section{Genotip-Özellik İlişkisinin GGE Biplot Analizi Ile Incelenmesi}

GGE biplot analizi genotipler ile özellikler arasındaki ilişkiyi görsel olarak sunmak suretiyle buğday ıslahçılarının işini kolaylaştırmaktadır. Biplot modelinin vektörler ile sunumunda, herhangi bir özelliği temsil eden vektör orijin merkezinden uzaklaştıkça yani vektör uzadıkça genotipler arasındaki varyasyon artmaktadır $[17,11]$.

$\mathrm{Bu}$ doğrultuda, araştırılan tüm özelliklerde varyasyonun yüksek olduğu görülmektedir (Şekil 2). Ayrıca, garafikte gösterilen vektörler arasındaki açı $<90^{\circ}$ pozitif, $>90^{\circ}$ negaif, $=90^{\circ}$ korelasyon yoktur şeklinde değerlendirilmektedir [18, 19, 20, 21]. Buna göre Şekil 2 değerlendirildiğinde, hektolitre ağırlığ ile bin tane ağırlığı arasında pozitif bir korelasyon, tane verimi ile protein oranı arasında ise negatif korelasyon olduğu açık bir şekilde görülmektedir. $\mathrm{Bu}$ ilişkiyi doğrulayan korelasyon tablosu önem seviyesini $\mathrm{p} \leq 0.01$ düzeyinde ortaya koymuştur (Tablo 6). Özellikler bazında öne çıkan genotipleri değerlendirdiğimizde tane veriminde; G23, G32, G71, G101, G113, hektolitre ağırlı̆̆ında; G16, G25, G29, G53 ve G76, bin tane ağırlığında; G48, G59, G65, G107 ve G109 protein oranında ise; G11, G13, G46, G53 ve G63 hatları ön sıralarda yer almıştır (Şekil 2 ve Tablo 5). 
İncelenen özellikler arasındaki korelasyonu (pozitif, negatif veya korelasyon yoktur) ve korelasyonun önem düzeyini gösteren Tablo 6 incelendiğinde bin tane ağırlığı ile hektolitre ağırlığı arasında pozitif ve önemli bir korelasyon olduğu belirlenirken, tane verimi ile protein oranı arasında ise önemli fakat, negatif bir korelasyon olduğu belirlenmiştir. Ayrıca bu sonuçların GGE biplot grafiğini teyit eder düzeyde önemli sonuçlar olduğu görülmüştür.

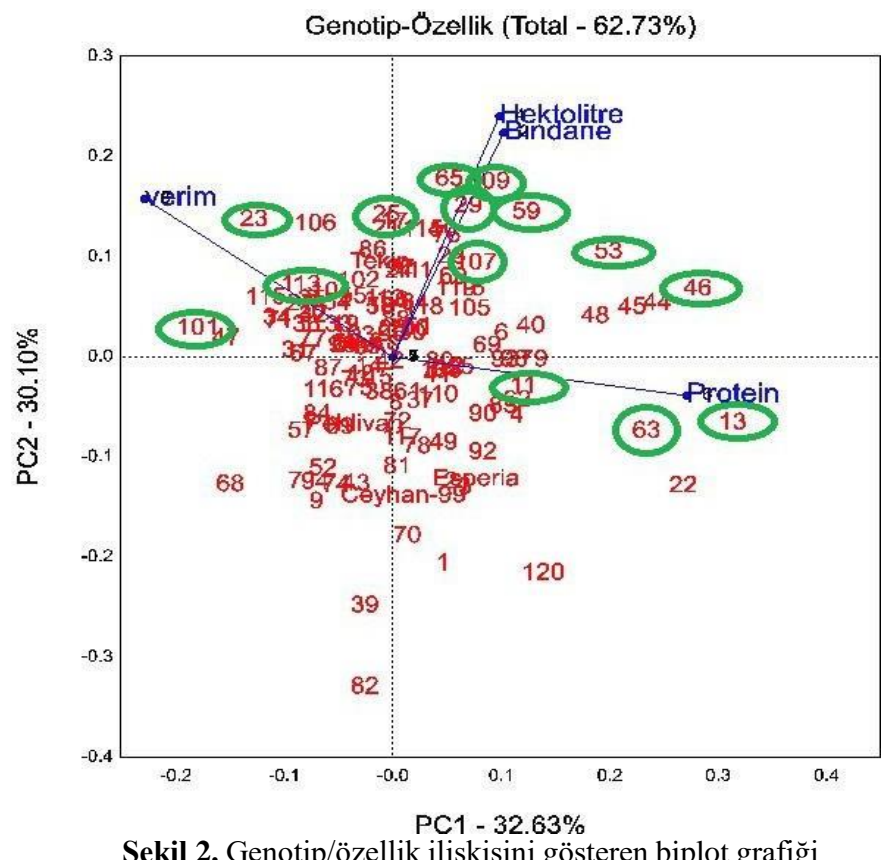

Tablo 6. İncelenen Özellikler Arasındaki İlişkiyi Gösteren Korelasyon Tablosu

\begin{tabular}{llll} 
Özellikler & Tane verim $\left(\mathbf{k g ~ d a}^{-\mathbf{1}}\right)$ & Hektolitre ağırlığı $\left(\mathbf{k g ~ h l}^{-\mathbf{1}}\right)$ & Protein oranı $(\%)$ \\
\hline Hektolitre ağırlığı & 0.0804 & - & - \\
Protein oranı & $-0.2521^{* *}$ & 0.0695 & - \\
Bin tane ağırlığ & 0.0486 & $0.2356^{* *}$ & 0.0581 \\
\hline
\end{tabular}

\section{SONUÇ}

Diyarbakır İli koşullarında Augmented Deneme Deseninde yağışa dayalı koşullarda yürütülen bu çalışma sonucunda; İncelenen tüm özelliklerde ümitvar hatlar olduğu belirlenmiştir. Hektolitre ağırlığ korelasyon olduğu belirlenirken, protein oranı ile tane verimi arasında negatif ve güçlü bir korelasyon olduğu görülmüştür. Araştırma konusu hatlar, incelenen özellikler yönünden kontrol çeşitler ile kıyaslandığında; tane veriminde hatların neredeyse tamamına yakını kontrol çeşitler (kontrol olarak kullanılan tüm çeşitler 'a' grubunda yer almıştır) ile aynı grupta yer almıştır. Hektolitre ağırlı̆̆ında; 5, bin tane ağırlığında; 66 , protein oranında; 46 hattın en yüksek değere sahip kontrol çeşitten daha üstün olduğu belirlenmiştir. Ümitvar olarak görülen hatlar (tane veriminde; G23, G32, G71, G101, G113, hektolitre ağırlığında; G16, G25, G29, G53 ve G76, bin tane ağırlığında; G48, G59, G65, G107 ve G109 protein oranında ise; G11, G13, G46, G53 ve G63) bir üst kademe olan ileri kademe verim denemelerine aktarılmıştır. Ayrıca, her bir özellikte en iyi olan hatlar 1slah programlarında ebeveyn olarak kullanılmak üzere tohumları muhafza altına alınmıştır. Çalışmada, verim denemelerine aktarılan hatların farklı çevrelerde en az 3 yıl denenmek suretiyle islah süreçlerinin devam ettirilmesi gerektiği sonucuna varılmıştır.

\section{TEŞEKKÜR}

Tarım ve Orman Bakanlığı, Tarımsal Araştırmalar ve Politikalar Genel Müdürlüğü bünyesinde faaliyetlerine devam eden ve bu projeyi (Proje Numaras1: TAGEM/TBAD/Ü/18/A7/P1/255) finansal olarak destekleyen GAP Uluslararası Tarımsal Araştırma ve Eğitim Merkezi'ne teşekkür ederiz.

\section{KAYNAKÇA}

[1] TMO. Toprak Mahsuller Ofisi Genel Müdürlüğü hububat sektör raporu. https://www.tmo.gov.tr/Upload/Document/sektorrap orlari/hububat2019.pdf. Erişim Tarihi: 01.05.2021. 
[2] TÜİK. Türkiye İstatistik Kurumu. Bitkisel üretim istatistikleri, tuik.gov.tr, 2020.

[3] Karaman M. Evaluation of the physiological and agricultural properties of some of bread wheat (Triticum aestivum L.) genotypes registered in Turkey Using Biplot Analysis. Pak. J. Bot., 52:6 1989-1997, 2020

[4] Stone P.J., Savin, R. Grain Quality and Its Physiological Determiants. in: Satorre M.H., Slafer G.A. Wheat, Ecology and Physiology of Yield Determination. Food Products Press, New York, p. 85120, 2000.

[5] Bonfil D.J., Karnieli A. Raz M. Mufradi I., Asido S., Egozi H., Hoffman A. Schmilovitch Z. Decision support system for improving wheat grain quality in the mediterranean area of Israel. Field Crop Research, 89 153-163, 2004.

[6] Peterson R.G. Agricultural Field Experiments Design and Analysis, Marcel Dekker,Inc. 409, 1994.

[7] Zadoks J.C., Chang T.T., Konzak C.F. A Decimal Code for The Growth Stages of Cereals. Weed Research, 14 415-421, 1974.

[8] Dokuyucu T., Akkaya A., Nacar A., İspir B. Kahramanmaraş koşullarında bazı ekmeklik buğdayların verim, verim unsurları ve fenolojik özelliklerinin incelenmesi, Türkiye II. Tarla Bitkileri Kongesi, 22-25 Eylül, 16-20, Samsun, 1997.

[9] Anıl H. Samsun ekolojik şartlarında yetiştirilen bazı ekmeklik buğday çeşitlerinde verim, verim unsurları ve kalite kriterlerinin belirlenmesi üzerine bir araştırma, Ondokuz Mayıs Üniversitesi, Ziraat Fakültesi, Tarla Bitkileri Bölümü Yüksek lisans tezi, Samsun, 2000.

[10] Doğan Y., Kendal E. Diyarbakır koşullarında bazı ekmeklik buğday (Triticum aestivum L.) genotiplerinin tane verimi ve bazı kalite özelliklerinin belirlenmesi, Yüzüncü Y1l Üniversitesi Tarım Bilimleri Dergisi, 23:3: 199-208, 2013.

[11] Karaman M. Seydoşoğlu S., Çam B. Diyarbakır ili koşullarında augmented deneme deseninde ekmeklik buğday (Triticum aestivum L.) Genotiplerinin Tarımsal Özellikler Yönünden İncelenmesi. Euroasia Journal of Mathematics, Engineering, 8:9 195-205, 2020.

[12] Özen S., Akman Z. Yozgat ekolojik koşullarında bazı ekmeklik buğday çeşitlerinin verim ve kalite özelliklerinin belirlenmesi, Süleyman Demirel Üniversitesi, Ziraat Fakültesi Dergisi, 10:1 35-43, 2015.

[13] Aktaş A. Bingöl ekolojik koşullarında bazı buğday (Triticum aestivum $L$.) çeşitlerinin verim ve kalite özelliklerinin belirlenmesi. Bingöl Üniversitesi Ziraat Fakültesi, Tarla Bitkileri Bölümü, Yüksek Lisans Tezi, s. 34, 2018.

[14] Koca Y.O., Dere Ş., Erekul O. İleri ekmeklik buğday hatlarında tane verimi ve bazı kalite özelliklerinin belirlenmesi. Adnan Menderes Üniversitesi, Ziraat Fakültesi Dergisi, 8:2 15-22, 2011.

[15] Anjum F.M., Ahmad I., Butt M.S., Sheikh M.A., Pasha I. Amino acid composition of spring wheats and losses of lysine during chapati baking, J. of Food Composition and Analysis, 18 523-532, 2005.

[16] Erekul 0., Yiğit A., Koca Y.O., Ellmer F., Weib K. Bazı ekmeklik buğday (Triticum aestivum L.) çeşitlerinin kalite potansiyelleri ve beslenme fizyolojisi açısından önemi. Tarla Bitkileri Merkez Araştırma Enstitüsü Dergisi, 25 31-36, 2016.

[17] Abate F., Mekbib, F., Dessalegn, F. GGE biplot analysis of multi-environment yield trials of durum wheat (Triticum turgidum Desf.) genotypes in North Western Ethiopia. American Journal of Expanded Agriculture, 8 120-129, 2015

[18] Erdemci İ. Investigation of genotype $\times$ environment interaction in chickpea genotypes using AMMI and GGE biplot analysis. Turk Journal of Field Crops, 23:1 20-26, 2018.

[19] Kendal E., Karaman M., Tekdal S., Doğan S. Analysis of promising barley (Hordeum vulgare L.) lines performance by AMMI and GGE biplot in multiple traits and environment. Applied Ecology and Environmental Research 17:2 5219-5233, 2019.

[20] Kendal E., Tekdal S., Karaman M. Proficiency of biplot methods (AMMI and GGE) in the appraisal of triticale genotypes in multiple environments, Applied Ecology and Environmental Research, 17:3 59956007, 2019.

[21] Karaman M. Evaluation of yield and quality performance of some spring bread wheat (Triticum aestivum L.) genotypes under rainfall conditions, International Journal of Agriculture, Environment and Food Sciences, 4:1 19-26, 2020. 